\title{
ENAM KONTINUM DALAM KONSELING TRANSGENDER SEBAGAI ALTERNATIF SOLUSI UNTUK KONSELI LGBT
}

\author{
Khilman Rofi Azmi \\ Bimbingan dan Konseling, Universitas Negeri Malang \\ email: rofiazmi@live.com
}

\begin{abstract}
Globalization caused by modern and dynamic society, creates several kinds of concepts, terms, and new theories today. The development in psychological science, and guidance and counseling are indicators of science development. Society problems come from the result of the change from that society, for example modern lifestyle that gives positive and negative impact. Transgender, gay, and lesbian phenomenon is one of the alternative lifestyle that spreads in Indonesia which is experienced by teenagers. It creates new problem for teenagers, their family, and their surroundings. The biggest problem in this case is there's no specific step for counselor and psychiatrist to help transgender, gay, or lesbian counselee. The new concept that offered in this article is Six Continuum of Transgender Counseling. Six continuum are aimed to give direction for counselor that may help gay, lesbian, and transgender counselee by doing counseling. Six continuum that have to be passed by counselor are (1) self, (2) relationship, (3) differential of feeling, (4) spiritual intervention, (5) acceptance of environment. Researchers are using literature study as their research method, by explored and examined some literatures: books, journal, dissertation, e-book, and some cases that happened in our society. This article especially developed and inspired by previous article. The article's tittle is Transgender Counseling Through (Wisdom-Oriented Counseling Approach).
\end{abstract}

Keywords: Transgender counseling, LGBT.

\begin{abstract}
Abstrak: Era globalisasi menyebabkan kehidupan dan dinamika kehidupan masyarakat modern,telah menciptakan sejumlah konsep, istilah dan teori baru. Perkembangan ilmu psikologi dan bimbingan dan konseling adalah indikator dari perkembangan tersebut. Masalah masalah yang timbul di masyarakat datang dari proses perubahan tersebut, seperti contoh gaya hidup modern yang memberikan dampak positif maupun dampak negatif. Fenomena transgender, gay, dan lesbian adalah salah satu alternatif gaya hidup yang dialami oleh beberapa masyarakat terutama remaja di Indonesia. Hal tersebut menciptakan sejumlah masalah tidak hanya pada remaja saja, namun juga keluarga, dan lingkungan konseli. Masalah terbesar dalam konteks ini adalah belum adanya langkah spesifik untuk konselor dan psikiater untuk menolong konseli dengan latar belakang transgender, gay dan lesbian. Konsep baru yang digagas dalam penelitian ini adalah enam kontinum konseling trangender. Enam kontinum ditujukan untuk membantu konseli melalui proses konseling. enam kontinum yang harus dilakukan oleh konselor antara lain : (1) diri (2) hubungan, (3) diferensiasi perasaan, (4) intervensi spiritual, (5) penerimaan diri terhadap lingkungan. Peneliti menggunakan studi literatur dalam metode penelitian ini, melalui pengkajian dari beberapa buku, jurnal, disertasi, e-book, dan sejumlah kasus yang terjadi di masyarakat. Artikel ini dikembangkan berdasarkan artikel peneliti sebelumnya. Artikel tersebut berjudul Transgender Counseling Through (WisdomOriented Counseling Approach).
\end{abstract}

Kata Kunci: Konseling transgender, LGBT. 


\section{PENDAHULUAN}

Gejolak dan proses serta dinamika di masyarakat dalam frame globalisasi yang melanda dunia modern telah melahirkan berbagai macam konsep, term dan bahkan teori baru. Perkembangan keilmuan psikologi, pendidikan serta bimbingan dan konseling menjadi salah satu indikator dari semakin pesatnya perkembangan ilmu dunia modern.

Konseling dalam seting pendidikan dituntut untuk mampu menjawab berbagai permasalahan serta problematika yang dialami oleh siswa. Terkait masalah yang dialami oleh siswa berkaitan dengan era kekinian antara lain adalah masalah yang berhubungan dengan pemanfaatan teknologi dan informasi, perbedaan budaya, isu-isu gender, gaya hidup dan masih banyak masalah lainnya. Menurut Elia (2007) gaya hidup dalam masyarakat dibagi menjadi dua yakni gaya hidup umum (the common lifestyle) dan gaya hidup alternatif (the alternative lifestyle). Gaya hidup umum (the common lifestyle) didefinisikan sebagai gaya hidup yang dijalani seseorang dengan mengikuti gaya hidup yang dijalani oleh mayoritas masyarakat yang lain. Sedangkan gaya hidup alternatif (the alternative lifestyle), merupakan gaya hidup yang cenderung "berbeda" dengan gaya hidup yang dijalani oleh kebanyakan orang lain. Gaya hidup inilah yang dapat menjadi sebuah potensi dari timbulnya permasalahan. Fenomena seperti transgender, gay dan lesbian merupakan salah satu contoh gaya hidup alternatif yang kini juga telah merambah di Indonesia, terutama melanda para remaja yang notabene masih dalam usia sekolah.

Jumlah penduduk yang gay dan lesbian menurut perhitungan dari hasil penelitian Alfred Kinsey (1948-1953) sekitar $10 \%$ dari total penduduk suatu negara. Namun, untuk negara dengan karakteristik seperti Indonesia, jumlahnya diperkirakan sekitar $1 \%$ dari total penduduk ( penelitian dilakukan oleh komunitas gay, Gaya Nusantara Surabaya). Namun, hasil penelitian yang berbeda diungkapkan oleh Permana Muhammad selaku Koordinator Sekretariat Nasional Jaringan Gay, Waria, dan lelaki yang berhubungan seks dengan lelaki (Gwl-Ina). Di Indonesia perkiraan jumlah gay dan lesbian sekitar 800 ribu. Hal tersebut perkiraan pada tahun 2009 dan diprediksikan akan terus meningkat dari tahun ke tahun.

Berdasarkan berbagai hasil penelitian tentang adanya transgender, gay dan lesbian terutama di seting sekolah, maka konselor dan profesi helper lainnya seperti psikolog dan bahkan psikiater sebagai salah satu komponen pendidikan dirasa perlu untuk mengatasi dan mengantisipasi segala bentuk potensi permasalahan yang muncul akibat fenomena tersebut. Konselor dan profesi helper lainnya seperti psikolog dan psikiater dengan segala karakteristik, nilai dan budaya yang ada pada dirinya diharapkan mampu menangani konseli dengan berbagai latar belakang nilai dan budaya yang berbeda termasuk gaya hidup alternatif yang dipaparkan diatas.

Menurut kajian Counseling and Mental Health Care of Transgender Adult and Loved One (2006) fenomena transgender muncul tidak hanya karena pengaruh lingkungan. Namun dalam sudut pandang ilmu kesehatan mental, transgender bisa muncul dipengaruhi oleh budaya, fisik, seks, psikososial, agama dan aspek kesehatan. Banyaknya penyebab muculnya fenomena transgender dapat menjadi kajian tersendiri bagi konselor dan profesi helper lainnya seperti psikolog dan psikiater yang menangani masalah tersebut. Semakin kompleks masalah yang dialami konseli, maka semakin memerlukan diagnosis khusus terhadap masalah tersebut.

Konteks yang lebih mendalam terkait dengan permasalahan yang muncul dari seorang konseli/klien yang mendefinisikan dirinya sebagai seorang lesbian, gay bisexsual dan transgender adalah munculnya masalah-masalah seperti (1) gambaran diri (2) gagal dan kerugian (3) isolasi sosial (4) fokus spiritual dan agama. Seluruh masalah tersebut menjadi "tantangan" bagi konselor dan profesi helper lainnya seperti psikolog dan psikiaterketika berhadapan dengan konseli/klien lesbian, gay, bisexsual dan transgender.

Melalui tulisan ini, penulis berupaya memberikan sebuah paradigma berfikir baru yang bersifat spesifik yang ditujukan kepada konselor dan profesi helper lainnya seperti psikolog dan psikiater yang menangani masalah lesbian, gay bisexsual dan transgender dalam seting konseling. Penulis juga berupaya membuat sebuah kontinum yang harus dilalui 
oleh konselor dan profesi helper lainnya seperti psikolog dan psikiater ketika menemui konseli/klien dengan latar belakang sebagai lesbian, gay bisexsual dan transgender. Melalui enam kontinum kesadaran yang digagas, maka konselor dan profesi helper lainnya seperti psikolog dan psikiater diharapkan mampu memperoleh titik terang dari masalah-masalah yang berkaitan dengan lesbian, gay bisexsual dan transgender.

\section{METODE}

Metodologi penelitian ini menggunakan penelitian berbasis studi literatur/studi pustaka yang dilakukan dengan mengkaji dan menggali berbagai teori dan praksis melalui literatur mulai dari buku, jurnal ilmiah, disertasi, e-book, internet dan berbagai data serta fakta yang ada dalam masyarakat, khususnya di sekolah.

Kaum Lesbian, Gay, Bisexual dan Transgender di Indonesia layak disebut sebagai sebuah fenomena gunung es karena yang tampak di permukaan adalah sangat sedikit namun, yang belum terungkap cukup signifikan. Indikator dari fenomena tersebut adalah dengan munculnya berbagai komunitas dan organisasi LGBT di setiap daerah di Indonesia.

Penelitian dan kajian yang mendalam terkait dengan Lesbian, Gay, Bisexual dan Transgender di Indonesia diakui belum terlalu banyak. Hal ini disebabkan dengan berbagai tantangan dan pro kontra yang terjadi dalam masyarakat. Bahkan mungkin saja belum banyaknya kajian mendalam tentang masalah ini adalah dikarenakan belum terlalu sadarnya para profesi helper untuk mengkaji fenomena yang sebenarnya sudah masuk dalam budaya di Indonesia.

Fenomena Lesbian, Gay, Bisexual dan Transgender dalam konteks budaya di Indonesia adalah hal yang masih tabu karena berbagai pihak menganggap bahwa LGBT merupakan perilaku yang abnormal. Konteks budaya Indonesia yang menjunjung tinggi adat ketimuran dirasa kurang cocok dengan munculnya fenomena tersebut. Walaupun, sejak hampir 10 tahun yang lalu, perilaku LGBT telah dinyatakan "keluar" dari DSM IV dan hal tersebut bermakna bahwa LGBT adalah perilaku yang normal. Dengan berbagai kajian tersebut, maka dapat digaris bawahi bahwa perilaku Lesbian, Gay, Bisexual dan Transgender tidak cocok dengan konteks perilaku "normal" masyarakat Indonesia saat ini dan tugas dari para helper yang melakukan konseling transgender adalah berfokus pada berbagai kemungkinan dampak psikis (pikiran, perasaan dan tingkah laku) dari perilaku tersebut.

Namun berbeda dengan di Amerika yang telah meletakkan frame konsep Lesbian, Gay, Bisexual dan Transgender dalam berbagai pendekatan kajian keilmuan yang termasuk didalamnya adalah konseling. Salah satu profesor konseling bernama Sharon G. Horne $\mathrm{Ph} . \mathrm{D}$ berasal dari University of Massachusetts Boston, Amerika Serikat menjadi "kiblat" bagi kajian keilmuan tentang Lesbian, Gay, Bisexual dan Transgender.

Penelitian terdahulu karya ilmiah ini berdasarkan pada salah satu penelitian yang ditulis oleh penulis sendiri yang kemudian dipresentasikan di kongres dan seminar internasional ABKIN (Asosiasi Bimbingan Konseling Indonesia) di Bali tahun 2013 berjudul "Transgender Counseling Through (Wisdom-Oriented Counseling Approach) "WOCA" In School. Penelitian pendahulu yang menjadi referensi dari karya ilmiah ini antara lain: (1) Student Prejudice againts gay male and lesbian lecturer (Ewing, Vanessa lynn,2003), (2) The Best of The Harvard Gay \&Lesbian Review (Ingram, Jeffery, 1997), (3) The Lesbian, Gay \&Bisexual Youth Program (LGBYP): A model for communities seeking to improve quality of life for lesbian, gay and bisexual youth (Travers, Robb; Paoletti, Dino, 1999), (4) Journal of Gay \&Lesbian Issues in Education ( Colford, Michael, 2003).

\section{HASIL DAN PEMBAHASAN}

Gagasan yang ditawarkan dalam karya ilmiah ini adalah Six continuum of Transgender Counseling (Enam Kontinum dari Transgender Counseling). Enam kontinum ini bertujuan untuk memberikan arahan bagi setiap konselor serta profesi helper lainnya seperti psikolog dan psikiater yang akan melakukan proses konseling dengan latar belakang lesbian, gay bisexsual dan transgender. Setiap kontinum merupakan sebuah tahapan yang harus dilalui konselor serta profesi helper lainnya seperti psikolog dan psikiater. Tidak diperbolehkan untuk melakukan 
lompatan-lompatan pada setiap kontinum karena setiap kontinum yang berupa tahapan konseling akan saling terkait. Satu saja konselor serta profesi helper lainnya seperti psikolog dan psikiater melewatkan satu kontinum sebagai tahapan yang harus dilakukan, maka kemungkinan yang terjadi adalah diagnosa yang kurang tepat terhadap masalah konseli. Keenam kontinum yang harus dilalui konselor serta profesi helper lainnya seperti psikolog dan psikiater antara lain:

Self Merupakan tahapan kontinum pertama yang menjadi salah satu titik penting dalam perjalanan kontinum yang selanjutnya. Self mengacu kepada diri seseorang berkaitan dengan seluruh identitas yang ada pada dirinya, contoh konkritnya adalah nama, alamat, nama orang tua, lingkungan keluarga dan pengaruhnya terhadap konseli dan aspek lain-lainnya yang berkaitan dengan diri.

Hal lain yang menjadi aspek penting dalam self adalah bagaimana konseli mampu menyadari identitas asli mereka dengan segala aspek bawaan yang ada pada dirinya. Tujuan utama dalam self adalah penggalian informasi yang lengkap terkait dengan jati diri konseli yang sebenarnya sesuai dengan apa yang mereka sadari sebelumnya.

Secara lebih konkrit digambarkan bahwa konseli dengan bantuan konselor serta profesi helper lainnya seperti psikolog dan psikiater harus mampu menyadari dirinya sesuai dengan identitas asli mereka. Jika dalam KTP (Kartu Tanda Penduduk) dan KTS (Kartu Tanda Siswa) tertulis sebagai laki-laki, maka jati diri sebenarnya adalah laki-laki dan begitu pula sebaliknya. Tidak ada yang ambigu dalam setiap identitas yang ada pada diri seseorang, dan hal inilah yang harus konseli sadari terlebih dahulu.

Relationship Merupakan kontinum kedua yang harus dialalui konselor serta profesi helper lainnya seperti psikolog dan psikiater ketika mengahadapi konseli dengan latar belakang lesbian, gay bisexsual dan transgender. Relationship mangacu pada diri seseorang untuk mampu memahami setiap hubungan yang ia jalin dan merujuk pada hubungan sosial. Setiap individu sebagai makhluk sosial pasti menjalin hubungan dengan orang lain, baik melalui dunia nyata maupun melalui dunia maya. Semua hubungan sosial yang dijalin merupakan salah satu hal yang perlu digali oleh konselor serta profesi helper lainnya seperti psikolog dan psikiater untuk mengetahui bagaimana tingkat hubungan sosial dengan sejenis atau dengan lawan jenis.

Walaupun ada stigma bahwa, hubungan sosial tidak selalu menjadi tolok ukur penilaian konselor serta profesi helper lainnya seperti psikolog dan psikiater untuk memberikan label lesbian, gay bisexsual dan transgender secara langsung, namun melalui hubungan sosial yang konseli jalin, maka menjadi sebuah data tersendiri bagi konselor serta profesi helper lainnya seperti psikolog dan psikiater untuk melihat apakah konseli termasuk "normal" atau sudah mengarah pada lesbian, gay bisexsual dan transgender.

hubungan sosial ini mempunyai beberapa aspek diantaranya: (1) Berkaitan dengan kisaaran jumlah teman laki-laki dan perempuan, (2) Berkaitan dengan bagaimana hubungan konseli dengan teman-teman dekatnya, (3) Berkaitan dengan karakterisitik teman-teman dan lingkungan yang menjadi tempat untu berhubungan secara sosial

Melalui beberapa aspek diatas, maka diharapkan akan memberikan sebuah data penting sebelum konselor serta profesi helper lainnya seperti psikolog dan psikiater memberikan sebuah label dan atau meng"iya"kan label yang dimiliki oleh konseli itu sendiri.

Differential of feeling. Berdasarkan pada kontinum sebelumnya, maka langkah kontinum selanjutnya adalah pengidentifikasian konseli terhadap perbedaan perasaan kepada temanteman dan lingkungan sekitarnya. Aspek perasaan atau afektif menjadi salah aspek yang sangat penting dalam menangani konseli/klien dengan label lesbian, gay bisexsual dan transgender. Perasaan menjadi salah satu tolok ukur yang harus digali oleh konselor serta profesi helper lainnya seperti psikolog dan psikiater. Aspek afektif berkaitan dengan beberapa hal seperti berikut: (1) Gender dan problematika yang menyertainya, (2) Bagaimana perasaan konseli terhadap teman-teman dekatnya, baik dengan lawan jenis, maupun dengan teman sejenis, (3) Eksplorasi masalah yang berkaitan dengan perasaan yang menyertai konseli, (4) Pemberian sebuah label terhadap konseli dengan berbagai pertimbangan yang mengacu pada perasaan.

Jika ditemukan bahwa konseli mempunyai perasaan yang "normal" terhadap dirinya dan 
juga hubungan dengan teman dekatnya, maka konselor serta profesi helper lainnya seperti psikolog dan psikiater bisa memberikan sebuah label normal kepada konseli, sedangkan jika konseli mengalami "perasan yang berbeda" seperti suka, cinta dan bahkan terobsesi yang berlebihan, maka konselor serta profesi helper lainnya seperti psikolog dan psikiater hendaknya segera melanjutkan pada tahap kontinum selanjutnya.

Identify mengacu pada identitas baru yang melekat pada diri konseli/klien. Pada tahapan kontinum ini , konseli diajak untuk mengkonstruk kembali pikiran, perasaan dan tindakan setelah melampaui beberapa kontinum selanjutnya. identfikasi diri ini akan menghasilkan sebuah "deklarasi pribadi" bahwa konseli telah mengaku sebagai orang yang normal atau menjadi seorang lesbian, gay, bisexsual dan transgender.

Deklarasi pribadi tersebut penting karena melalui identify tersebut, maka akan semakin mengukuhkan konseli pada jati diri yang ia lekatkan sendiri pada dirinya. Setiap pilihan dari pengkuan ini akan menimbulkan konsekuensikonsekuensi yang menyertainya.

Tugas konselor serta profesi helper lainnya seperti psikolog dan psikiater dalam seting konseling adalah memberikan fasilitasi pada konseli untuk menemukan jati diri mereka yang seharusnya normal dan jika konseli/klien tetap teridentifikasi sebagai lesbian, gay bisexsual dan transgender, maka langkah selanjutnya adalah masuk pada kontinum lanjut yakni spiritual

Spiritual Intervention. Kontinum selanjutnya adalah spiritual intervention yang mengacu pada intervensi konselor serta profesi helper lainnya seperti psikolog dan psikiater terhadap konseli yang telah mendeklarasikan dirinya sebagai lesbian, gay bisexsual dan transgender. Kontinum ini menjadi salah satu kontinum yang mungkin tidak dibahas dalaam seting konseling di negara-negara barat. Hal ini tentu saja dikarenakan topik agama merupakan salah satu topik yang sensitif dan bersifat pribadi sehingga mungkin tidak pernah digunakan oleh para konselor serta profesi helper lainnya seperti psikolog dan psikiater di negara-negara barat kecuali dalam seting konseling pastoral atau konseling berbasis agama lainnya.

Namun berbeda dengan di Indonesia yang dikenal sebagai negara yang berketuhanan yang maha esa dengan selalu memberikan pengaruh agama dalam setiap lini kehidupan masyarakat. Spiritual menjadi pintu intervensi terakhir bagi konselor serta profesi helper lainnya seperti psikolog dan psikiater dalam upaya mengembalikan jati diri konseli sehingga bisa tumbuh sehat secara mental dengan lingkungan sekitarnya.

Menurut hemat penulis, hampir setiap agama melarang perbuatan yang mengacu pada lesbian, gay bisexsual dan transgender. Kecuali pada transgender yang mungkin dikarenakan adanya perubahan kelamin secara tidak sengaja dan bersifat alamiah yang memungkinkan konseli untuk berubah atau berganti kelamin. Larangan agama menjadi aspek yang harus dipegang oleh setiap konselor serta profesi helper lainnya seperti psikolog dan psikiater untuk memberikan perlakuan dan pengetahuan tentang bahaya lesbian, gay bisexsual dan transgender serta resiko dan konsekuensi dari lingkungan, agama dan nilai-nilai moral yang menyertainya.

Spritiual intervention menjadi salah satu titik kontinum penting dalam memberikan pengetahuan kepada konseli tentang lesbian, gay bisexsual dan transgender sekaligus menjadi benteng terakhir bagi konselor serta profesi helper lainnya seperti psikolog dan psikiater dalam usaha-usaha sadar untuk mengembalikan konseli/klien menemukan jati diri mereka.

Acceptane of environmental. Kontinum yang terakhir menjadi puncak dari semua kontinum yang telah dilalui oleh konselor serta profesi helper lainnya seperti psikolog dan psikiater. untuk penerimaan diri terhadap lingkungan mengacu pada masalah-masalah yang mungkin dihadapi konseli/klien dalam proses penyesuaian diri terhadap lingkungan. Lingkungan baru mungkin saja belum bisa menerima kehadiran sosok konseli yang telah mendeklarasikan dirinya menjadi lesbian, gay bisexsual dan transgender.

Namun hal prinsip yang harus dipegang oleh konselor serta profesi helper lainnya seperti psikolog dan psikiater adalah bahwa profesi ini sangat dimungkinkan tidak menyetujui setiap apa yang telah diutuskan oleh konseli/klien, tetapi semua keputusan tetap ada ditangan konseli dengan mempertimbangkan segala konsekuensi yang menyertai. Konselor serta profesi helper lainnya seperti psikolog dan psikiater mungkin merasa bertentangan dengan 
nilai dan moral agama jika pada akhirnya konseli menjadi seorang dengan label lesbian, gay bisexsual dan transgender. Namun, tugas konselor serta profesi helper lainnya seperti psikolog dan psikiater bukan harus menyetujuinya, namun memberikan wawasan terhadap setiap pilihan konseli. Termasuk dalam konteks kontinum yang terakhir ini adalah bagaimana konseli mampu diterima di masyarakat dengan segala bentuk masalah dan dinamika problematik didalamnya.

Tabel 1.1 Grand Design The Six Continuum of Transgender Counseling

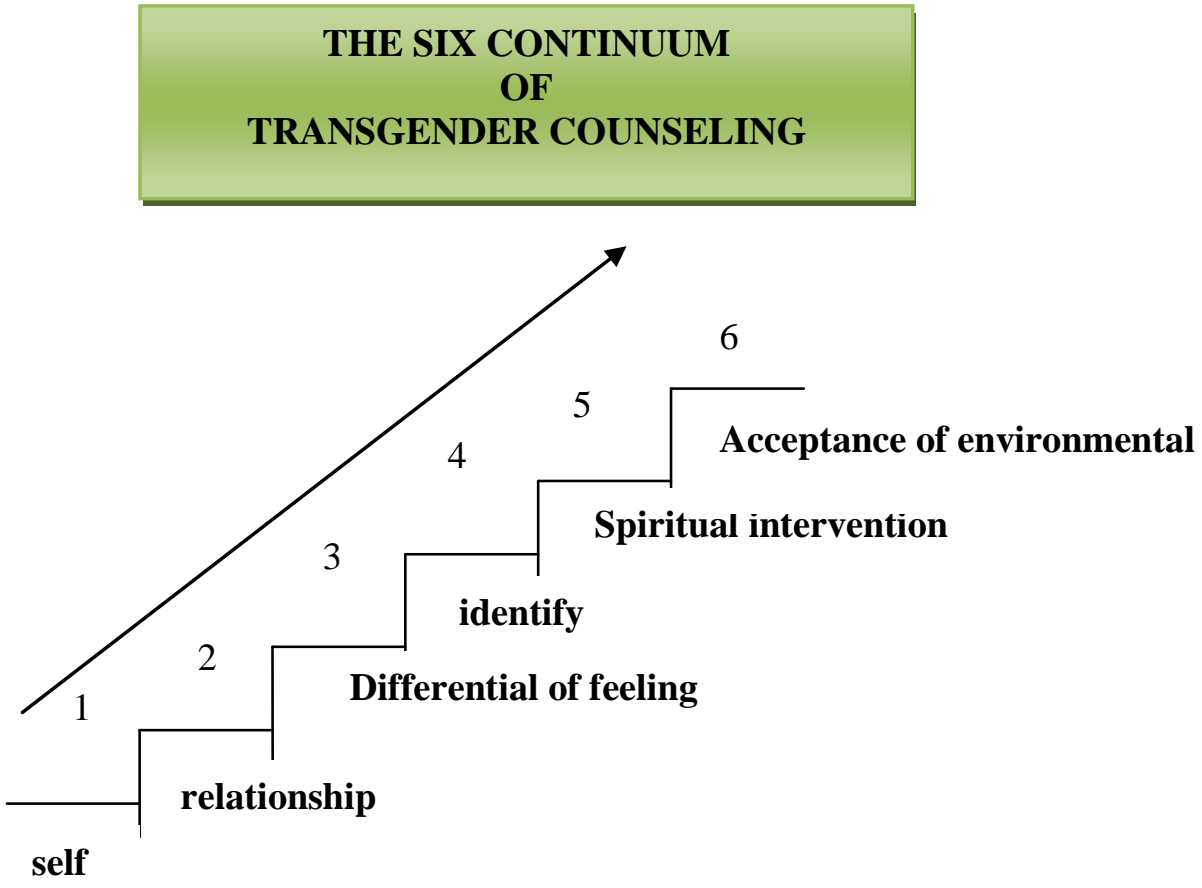

\begin{tabular}{|c|c|c|}
\hline No & Part Of Continuum & Indicators \\
\hline 1 & Self & $\begin{array}{ll}\text { - } & \text { Name,date and specific identity } \\
\text { - } & \text { Sex } \\
\text { - } & \text { Past experience }\end{array}$ \\
\hline 2 & Relationship & $\begin{array}{ll}\text { - } & \text { Friends } \\
\text { - } & \text { Close friends } \\
\text { - } & \text { Click } \\
\text { - } & \text { Amount of friends }\end{array}$ \\
\hline 3 & Differential of feeling & $\begin{array}{l}\text { - } \quad \text { Gender } \\
\text { - } \quad \text { How your feeling about your friends? } \\
\text { - } \quad \text { Sex orientation }\end{array}$ \\
\hline 4 & Identify & - Confenssion of as... \\
\hline 5 & Spiritual intervention & $\begin{array}{ll}\text { - } & \text { Universal value } \\
\text { - } & \text { Past experience } \\
\text { - } & \text { Preposition thorem/postulate }\end{array}$ \\
\hline 6 & Acceptance of environmental & - Problem identify \\
\hline
\end{tabular}


- Manage problem

- Solution to change

- Follow up

\section{SIMPULAN DAN SARAN}

Mengacu pada rumusan masalah dan tujuan dalam penulisan karya ilmiah ini, maka dapat disimpulkan bahwa : (1) Mulai maraknya

fenomena masyarakat terkait dengan lesbian, gay bisexsual dan transgender perlu mendapat perhatian khusus dari para profesi helper termasuk konselor serta profesi helper lainnya seperti psikolog dan psikiater; (2) Belum adanya tahapan spesifik yang dilakukan konselor serta profesi helper lainnya seperti psikolog dan psikiater ketika menangani konseli dengan latar belakang lesbian, gay bisexsual dan transgender menjadi masalah tersendiri bagi konselor serta profesi helper lainnya seperti psikolog dan psikiater. (3) Penulis menawarkan sebuah gagasan yang berlandaskan teori-teori terdahulu yakni enam kontinum dalam Transgender Counseling; (4)Melalui gagasan yang ditawarkan penulis, maka diharapkan akan sangat mempermudah langkah konselor serta profesi helper lainnya seperti psikolog dan psikiater ketika menangani masalah terkait dengan lesbian, gay bisexsual dan transgender; (5) Gagasan enam kontinum dalam Transgender Counseling telah disesuaikan dengan karakteristik budaya dan nilai-nilai moral agama yang menyertai masyarakat di Indonesia sehingga cocok untuk dipergunakan konselor serta profesi helper lainnya seperti psikolog dan psikiater yang menangani masalah lesbian, gay bisexsual dan transgender.

Menjawab berbagai tantangan yang dialami konselor serta profesi helper lainnya seperti psikolog dan psikiater atau psikolog dan profesi helper lainnya, maka penulis merekomendasikan sebuah gagasan baru untuk mengatasi masalah-masalah lesbian, gay, bisexsual dan transgender melalui Enam Kontinum dalam Trangender Counseling. Sebuah gagasan baru yang harus dilalui konselor serta profesi helper lainnya seperti psikolog dan psikiater ketika menemui konseli/klien dengan latar belakang lesbian, gay bisexsual dan transgender.

Rekomendasi melalui transfer gagasan yang mungkin dikembangkan oleh penulis selanjutnya adalah penelitian lebih intensif dan bersifat komprehensif terkait dengan penyelesaian masalah lesbian, gay bisexsual dan transgender melalui enam kontinum dalam Transgender Counseling. Penelitian bisa langsung terjun ke lapangan dan melihat berbagai fenomena terkait dengan lesbian, gay bisexsual dan transgender.

Bagi masyarakat kiranya penting untuk lebih peka terhadap dinamika perubahan dalam konteks kemasyarakatan. Jangan sampai sebuah fenomena luput dari penglihatan mata sehingga jika fenomena tersebut berdampak pada kerusakan moral dan turunnya nilai agama, maka hendaknya perlu ditangani secara lebih kompleks dan nyata serta penanganan yang cepat tanggap dan tepat.

\section{DAFTAR RUJUKAN}

Baltes, P.B.\& Staudinger, U.M.(2000). Wisdom :A metahuristic(pragmatic) to orchestrate mind and virtue toward excellence. American Psychologist,2(1),122-136

Colford.2003.Journal of Gay \&Lesbian Issues in Education.New York: Publishing and Trade Book.

Erwing.2003.Student Prejudice againts gay male and lesbian lecturer.Washington:Taylor and Francis inc.

Flurentin, Elia.(2007). Konseling Multibudaya. Malang: Universitas Negeri Malang.

Hanna,F.J. Ottens,A.J.(1995). The role of wisdom in psychotherapy. Journal of psychotherapy Integration, 5,199-219.

Ingram.1997.The Best of The Harvard Gay \& Lesbian Review. New York: Publishing and Trade Book.

Jurnal Kedokteran.2008.The Medical Journal.Volume 7.113

Kensey A. 1953.The Research of Gay and Counseling Perception.Boston: Basic books 
57 | Jurnal Psikologi Pendidikan \& Konseling Vol. 1 Nom. 1 Juni 2015.

Sharon. P.2006.Counseling and Mental Health Care of Transgender Adult and Loved One. New York: Sage Publication.

Travers.1999.The Lesbian, Gay \&Bisexual Youth Program (LGBYP): A Model for Communities Seeking To Improve Quality of Life for Lesbian, Gay and Bisexual Youth.Canada: Sex Information and Education Council of Canada. 